\title{
Compartmentalization of the gut viral reservoir in HIV-I infected
} patients

\author{
Guido van Marle*1, M John Gill ${ }^{1}$, Dione Kolodka ${ }^{1}$, Leah McManus ${ }^{1}$, \\ Tannika Grant ${ }^{1}$ and Deirdre L Church ${ }^{1,2,3}$
}

Address: ${ }^{1}$ Department of Microbiology and Infectious Diseases, University of Calgary, Calgary, Alberta, Canada, ${ }^{2}$ Department of Pathology and Laboratory Medicine, University of Calgary, Calgary Alberta, Canada and ${ }^{3}$ Division of Microbiology, Calgary Laboratory Services, Calgary, Alberta, Canada

Email: Guido van Marle* - vanmarle@ucalgary.ca; M John Gill - john.gill@crha-health.ab.ca; Dione Kolodka - dukolodk@ucalgary.ca; Leah McManus - lsmcmanu@ucalgary.ca; Tannika Grant - tgrant@ucalgary.ca; Deirdre L Church - deirdre.church@cls.ab.ca

* Corresponding author

Published: 4 December 2007

Retrovirology 2007, 4:87 doi:10.1 186/1742-4690-4-87

This article is available from: http://www.retrovirology.com/content/4/I/87

(c) 2007 van Marle et al; licensee BioMed Central Ltd.

This is an Open Access article distributed under the terms of the Creative Commons Attribution License (http://creativecommons.org/licenses/by/2.0), which permits unrestricted use, distribution, and reproduction in any medium, provided the original work is properly cited.

\begin{abstract}
Background: Recently there has been an increasing interest and appreciation for the gut as both a viral reservoir as well as an important host-pathogen interface in human immunodefiency virus type I (HIV-I) infection. The gut associated lymphoid tissue (GALT) is the largest lymphoid organ infected by HIV-I. In this study we examined if different HIV-I quasispecies are found in different parts of the gut of HIV-I infected individuals.
\end{abstract}

Results: Gut biopsies (esophagus, stomach, duodenum and colorectum) were obtained from eight HIV-I infected preHAART (highly active antiretroviral therapy) patients. HIV-I Nef and Reverse transcriptase (RT) encoding sequences were obtained through nested PCR amplification from DNA isolated from the gut biopsy tissues. The PCR fragments were cloned and sequenced. The resulting sequences were subjected to various phylogenetic analyses. Expression of the nef gene and viral RNA in the different gut tissues was determined using real-time RT-PCR. Phylogenetic analysis of the Nef protein-encoding region revealed compartmentalization of viral replication in the gut within patients. Viral diversity in both the Nef and RT encoding region varied in different parts of the gut. Moreover, increased nef gene expression $(p<0.05)$ and higher levels of viral genome were observed in the colorectum $(p<0.05)$. These differences could reflect an adaptation of HIV-I to the various tissues.

Conclusion: Our results indicated that different HIV-I quasispecies populate different parts of the gut, and that viral replication in the gut is compartmentalized. These observations underscore the importance of the gut as a host-pathogen interface in HIV-I infection.

\section{Introduction}

Recently there has been an increasing interest and appreciation for the gut as a viral reservoir and an important host-pathogen interface in human immunodefiency virus type 1 (HIV-1) infection [1-4]. The gut associated lym- phoid tissue (GALT) is the largest lymphoid organ infected by HIV-1. Studies on simian immunodeficiency virus (SIV) have indicated the gut is an important site for CD4+ T-cell depletion $[1,4]$, and this appears to be similar in humans [5]. The inflammatory milieu in the gut is con- 
sidered to play a key role in $\mathrm{CD}^{+}$cell loss, as a lack of $\mathrm{CD} 4{ }^{+}$cell replenishment in the gut of HAART treated HIV1 infected individuals was associated with increased inflammatory gene expression and immune activation [2]. These observations have also led to the hypothesis that HIV-1 may "hide" from antiretroviral therapy in the gut [2]. This would be consistent with the notion that the gut could act as a separate reservoir for viral replication [6]. However, very little is known about the HIV-1 quasispecies that reside in the gut.

Viral variability significantly affects pathogenesis and infection. Disease progression in HIV-1 infection is accompanied by an increasing diversity in viral sequences found within the infected individual [7]. HIV-1 is highly divergent due to the error-prone reverse transcription step in the HIV-1 life cycle [8]. Factors such as viral fitness, availability of target cells for infection, antiretroviral therapy, duration of infection and the host immune response influence which viral quasispecies arise during the course of infection [9-13]. For both SIV and HIV-1 it has been suggested that the immune system can push viral evolution towards HIV-1 quasispecies with increased pathogenic properties [7,14-17]. In HIV/AIDS patients on antiretroviral therapy, viral sequences evolved over time in genes not targeted by the drugs, despite undetectable plasma viral loads [18-20]. These observations suggested that viral replication continued in tissues or cell compartments not efficiently targeted by the antiretroviral drugs. The contribution of the gut to increasing viral diversity in the host is unresolved. In addition, it is unclear to what extent viral replication in the gut is compartmentalized. The distribution and composition of the lymphoid tissues vary amongst different locations in the gut. For instance, lymphocytes in the small intestine can be found in organized structures, so-called Peyer's patches, but are also found in the lamina propria and as intraepithelial lymphocytes throughout the gut (reviewed in [21]). The Peyer's patches are found in the duodenum, but their frequency increases further down the small intestine, with the largest number present in the ileum (reviewed in [22]). In humans, lymphocytes in the large intestine (i.e. cecum, colon and rectum) are found as isolated lymphoid follicles, with the highest frequency in the rectum $[23,24]$. The distribution of the type of T-cells in the GALT is different than the periphery, as $70 \%$ of the intraepithial lymphocytes in the small intestine are CD8+ T-cells [25]. Moreover, throughout the intestine the majority of $\mathrm{CD} 4^{+}$ T-cells are CCR5 positive [26]. Therefore, the different parts of the gut could select for different HIV-1 quasispecies, and thus act as reservoirs for different viral strains.

The goal of the current study was to determine if viral replication in the gut is compartmentalized. We analyzed HIV-1 sequences of the Nef (negative factor) and the reverse transcriptase (RT) encoding region amplified by PCR from biopsy material taken from different locations within the gut of HIV-1 infected individuals. These analyses demonstrated that for both RT and the Nef encoding region viral diversity differed significantly among the various gut tissues, and phylogenetic analyses clearly demonstrated clustering of nef DNA sequences at different sites. Furthermore, our observations suggested compartmentalization of HIV-1 replication in different parts of the gut, and indicated that the gut is a distinct multi-compartment viral reservoir in HIV-1 infected individuals.

\section{Results \\ Clustering of HIV-I nef sequences by gut tissue compartment}

To get insight into potential compartmentalization of HIV-1 replication at different locations within the gut, we focused on analyzing the Nef and RT encoding regions of HIV-1. These regions were amplified by nested PCR from DNA isolated from different gut tissues (esophagus, stomach, duodenum and colorectum) and peripheral blood lymphocytes (PBL). The samples were obtained from a previously described cohort of HIV seropositive homosexual men followed at the Southern Alberta Clinic (SAC), Calgary, Alberta, from 1993 to 1996 [6,27]. This cohort was recruited prior to the introduction of HAART (Highly Active Antiretroviral therapy) at the SAC in late 1997. Eight patients at various clinical stages of HIV infection/ AIDS were selected and gut tissue samples from one visit were analyzed (Table 1). Although cDNA was synthesized and viral sequences could be detected with our real-time RT-PCR analysis using small amplicons (discussed in sections below), the sequences spanning the entire viral regions of interest were the most readily and consistently amplified from DNA. Therefore, we focused on these proviral sequences for the current study. Analysis of these sequences also exploits the "banking-effect" of proviral DNA in the chromosomal DNA of different cell populations offering some insight into "the history" of the infection [28] and seeding of the gut tissues. We chose to

Table I: Patients

\begin{tabular}{cccc}
\hline Patient & $\begin{array}{c}\text { Viral load } \\
\text { Log(copies)/mL* }\end{array}$ & CD4 $^{+}$Cells/mL* & $\begin{array}{c}\text { Antiretroviral } \\
\text { Drugs* }\end{array}$ \\
\hline$\#$ I & 2.7 & 264 & ddl, AZT \\
$\# 2$ & 5.8 & 18 & None \\
$\# 3$ & 5.6 & 77 & AZT \\
$\# 7$ & 4.5 & 146 & AZT \\
$\# 8$ & 4.4 & 325 & ddl \\
$\# 19$ & 3.9 & 77 & ddl \\
$\# 42$ & 5.6 & 9 & None \\
$\# 60$ & 4.5 & 48 & AZT
\end{tabular}

* Viral loads, CD4 ${ }^{+}$counts and antiretroviral therapy at time biopsies were collected 
analyze the HIV-1 Nef and RT protein encoding sequences as these proteins have various effects on viral replication and the RT region has been shown to evolve by tissue compartment $[8,29-31]$. Both proteins are targeted by the cellular immune response [32-34], and therefore suitable targets to determine how HIV-1 evolves in different parts of the gut. The Nef protein is highly variable [32], but is relatively more conserved than the highly diverse envelope protein [35], which could make it easier to detect phylogenetic relationships within the patient population. Finally, the Nef protein has been implicated as an important pathogenic determinant of HIV-1 [36-47], and its analysis could shed some light on the evolution of pathogenic HIV-1 strains in the gut.

HIV-1 viral sequences were amplified from PBL and biopsy tissue DNA using our nested PCR protocol. For seven patients RT and Nef encoding sequences were obtained from 3 or more tissues (gut tissues and/or PBL), while for one patient (\#8) only sequences from two tissues could be obtained (stomach and esophagus). Neighbour-Joining trees revealed clustering of the nef sequences by individual patient (bootstrap values of >90) (Fig. 1). The clones of the Nef encoding sequences also clustered by gut tissue from which they were obtained (i.e. esopha-

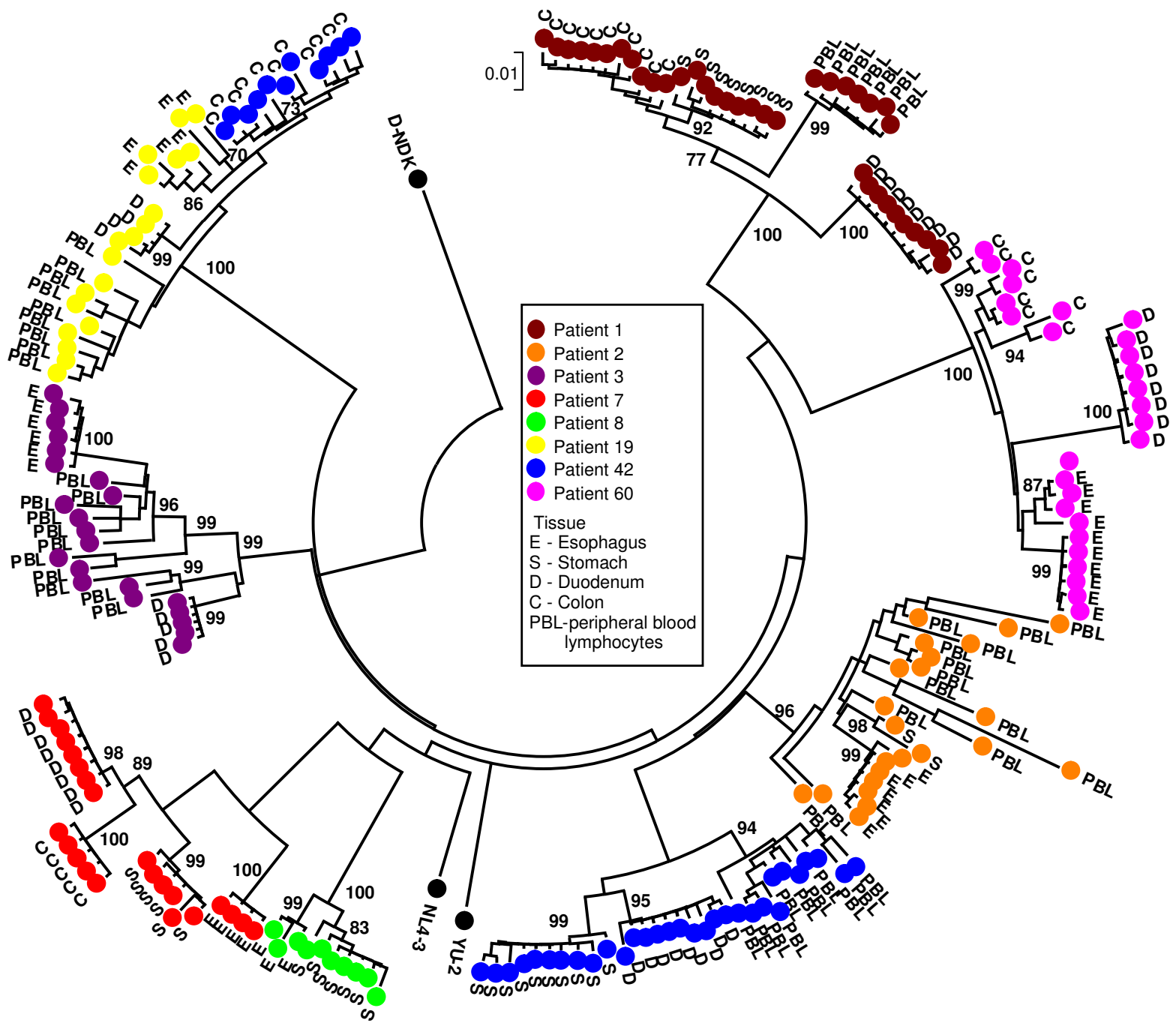

Figure I

Bootstrap Neighbor-Joining tree of the sequences of the Nef encoding region obtained from gut tissues. Nef sequences clustered by individual patients (indicated by colors). Closer examination of these sequences revealed clustering of Nef sequence by tissue compartment (esophagus (E), stomach (S), duodenum (D), colorectum (C) and PBL) within patients, indicative of compartmentalization of viral replication in the gut, resulting in the evolution of different HIV-I quasispecies in different parts of the gut. (Bootstrap values $>70$ are indicated.) 
gus, stomach, duodenum and colorectum). No mixed clustering with sequences of different tissues was observed, indicating that within a patient distinct HIV-1 quasispecies were found within different parts of the gut. Analysis of the clustering pattern for the patients for which we were able to obtain viral sequences from PBL revealed clustering of these sequences with each other (bootstrap value >90) (Fig. 1). This indicated that the viral quasispecies found in the periphery were different from those found in the gut. No obvious phylogenetic relation- ship of PBL sequences with sequences of a particular gut tissue (i.e. esophagus, stomach, duodenum or colon) was observed among the different patients. In contrast to the Nef encoding region, similar tight clustering for the RT encoding region was not found for any of the patients (Fig. 2). However, for various patients a large number of the RT encoding sequences from the esophagus and stomach clustered together. The latter could suggest that there may be a selection for a particular RT encoding sequence in these tissues among patients.

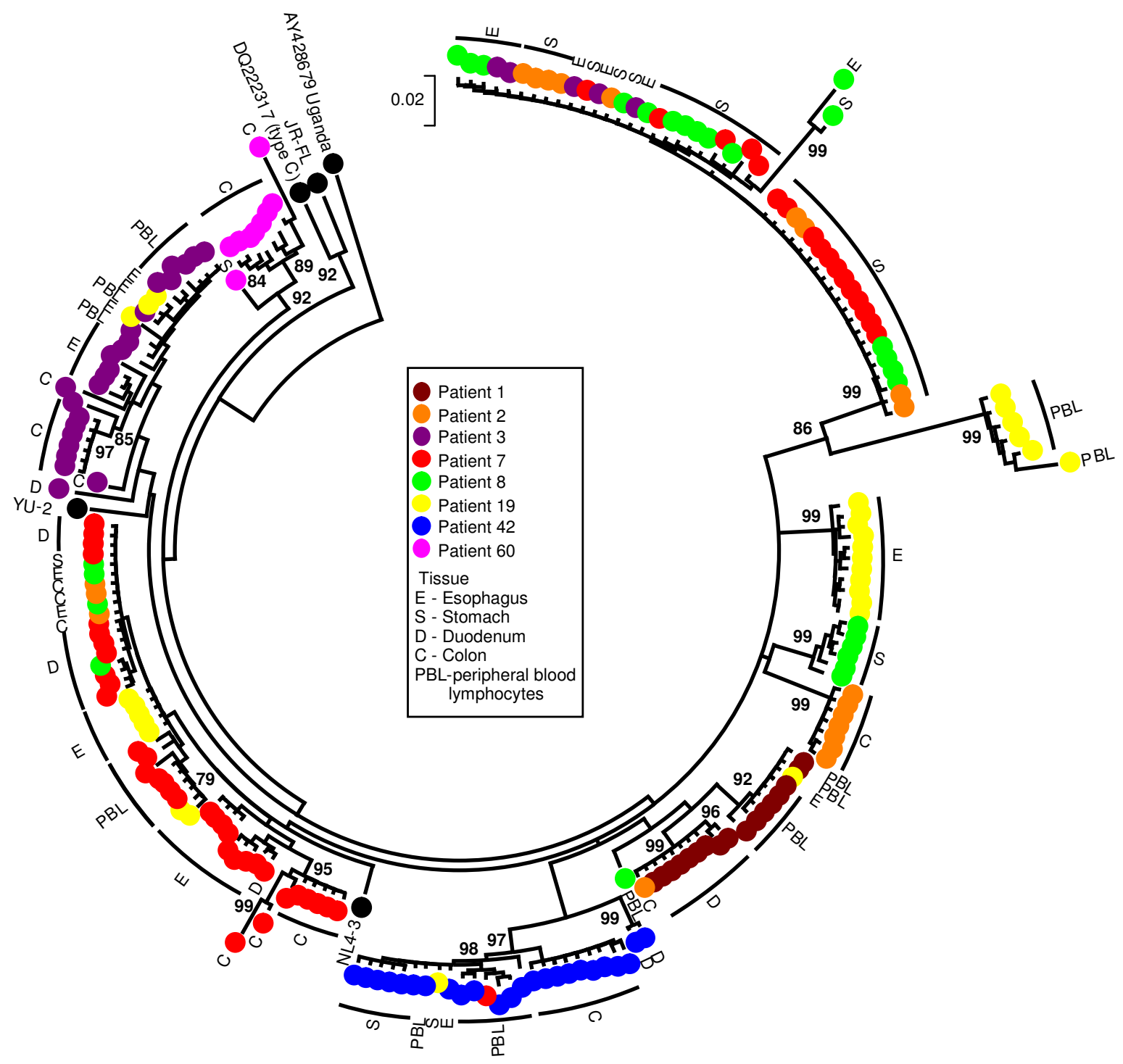

\section{Figure 2}

Bootstrap Neighbor-Joining tree of RT encoding sequences obtained from gut tissues. Clustering was observed of RT encoding sequences by patient and tissue but not to the same extent as observed for the Nef encoding sequences. Closer examination of the tree revealed clustering of a large number of sequences derived from the esophagus and stomach from different patients, suggesting some selection for esophagus and stomach specific RT encoding sequences. (Bootstrap values $>70$ are indicated.) 
To corroborate our observations, the sequences from all clones for the Nef and the RT encoding region were used to derive consensus sequences for each tissue compartment for each patient. Bootstrap analysis of these consensus sequences revealed clustering of nef sequences by patient, and for two patients by upper (esophagus and stomach) and lower (duodenum and colorectum) gut tissue compartment (Fig. 3A) (bootstrap value >90). This suggested a clustering of nef sequences by upper or lower GI-tract in select patients. Similar to our previous results,
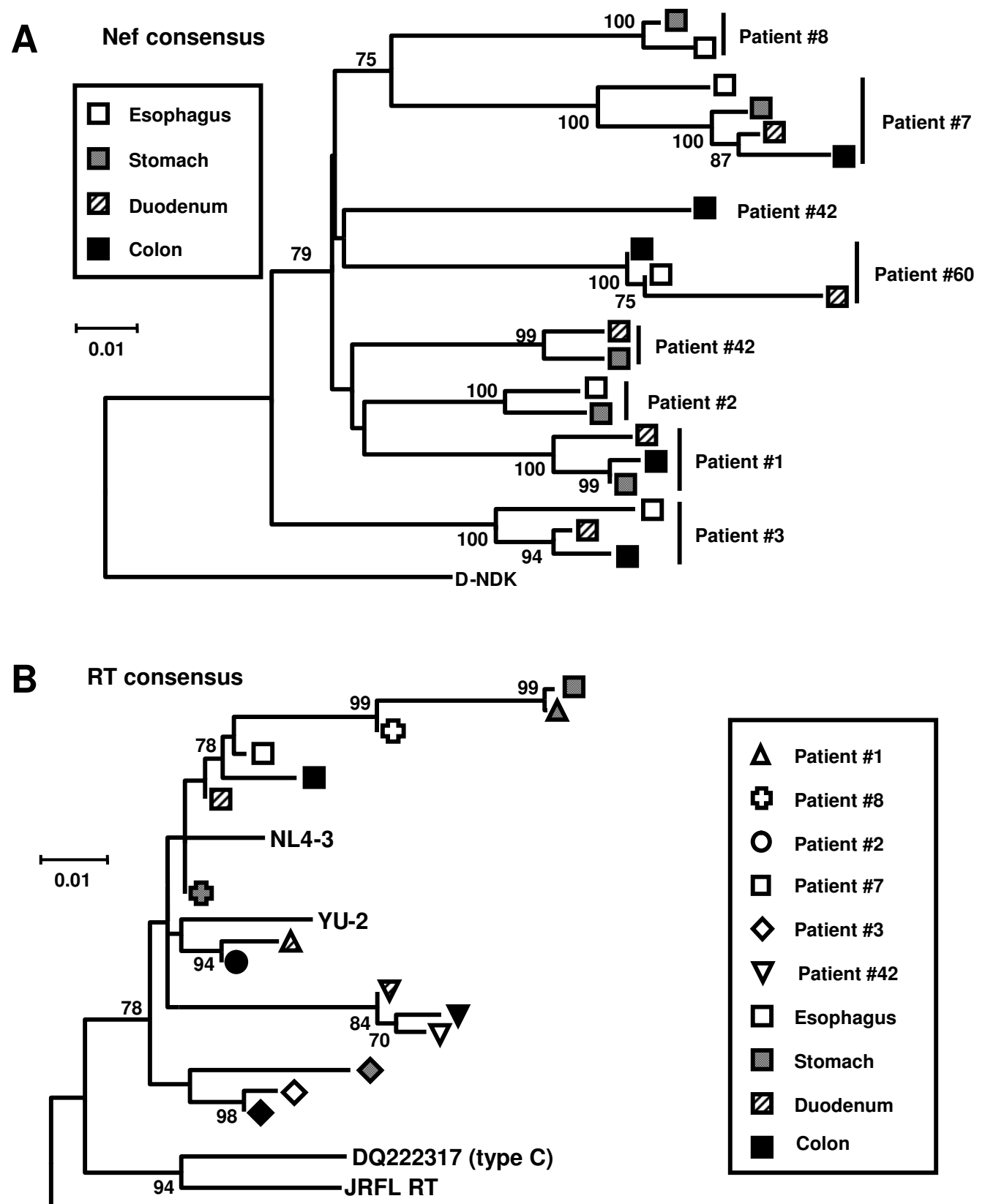

AY428679 Uganda

Figure 3

Neighbor-Joining tree of the consensus sequences of the Nef and RT encoding region from gut tissues. While no obvious clustering was observed for the RT (B), Nef encoding sequences clustered by individual patients (A). In patients 3 and 7 further clustering of sequences by upper (esophagus and stomach) or lower (duodenum and colorectum) gut tissues was observed. (Bootstrap values $>70$ are indicated). 
clustering was again not observed for the RT encoding region (Fig. 3B). Analysis of the consensus Nef protein sequences obtained (Fig. 4) did not reveal any particular signature sequences for specific gut tissues. Taken together, these observations indicated that viral replication in the gut was compartmentalized, resulting in different HIV-1 quasispecies populating different parts of the gut.

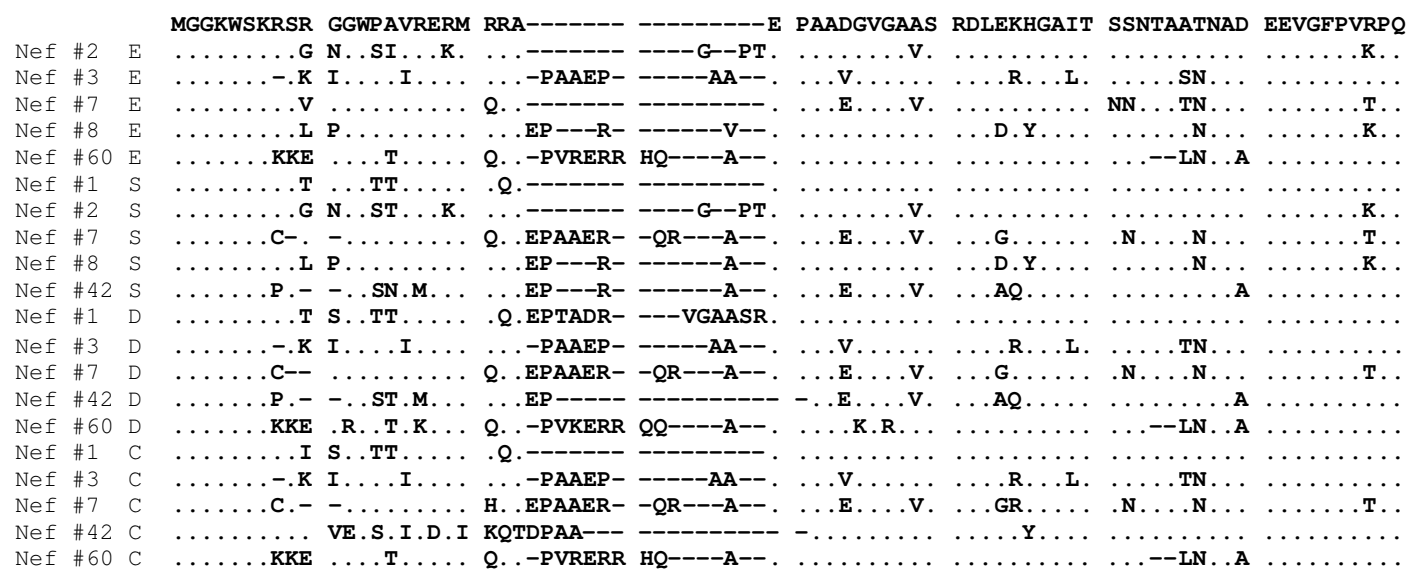

VPLRPMTYKG AVDLSHFLKE KGGLEGLIYS QKRQDILDLW VYHTQGYFPD WQNYTPGPGV RYPLTFGWCF KLVPVEPDKV

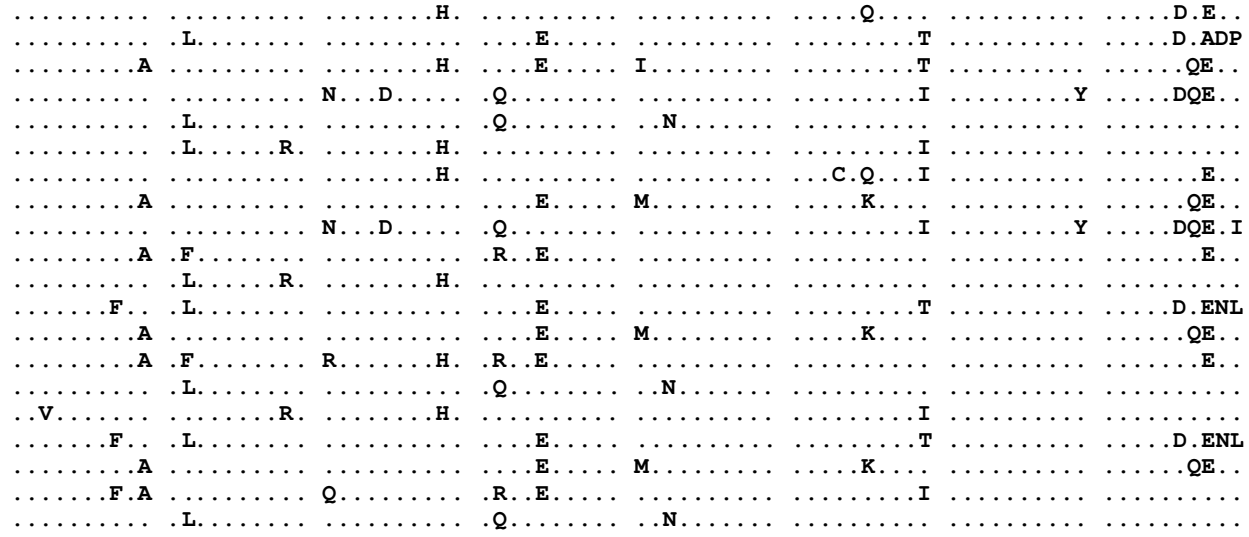

$\begin{array}{lll}\text { Nef } \# 2 & E \\ \text { Nef } \# 3 & E \\ \text { Nef } \# 7 & E \\ \text { Nef } \# 8 & E \\ \text { Nef } \# 60 & E \\ \text { Nef } \# 1 & S \\ \text { Nef } \# 2 & S \\ \text { Nef } \# 7 & S \\ \text { Nef } \# 8 & S \\ \text { Nef } \# 42 & S \\ \text { Nef } \# 1 & D \\ \text { Nef } \# 3 & D \\ \text { Nef } \# 7 & D \\ \text { Nef } \# 42 & D \\ \text { Nef } \# 60 & D \\ \text { Nef } \# 1 & C \\ \text { Nef } \# 3 & C \\ \text { Nef } \# 7 & C \\ \text { Nef } \# 42 & C \\ \text { Nef } & \text { C } 60 & C\end{array}$

\begin{tabular}{|c|c|c|c|c|c|c|}
\hline EANEGENNS & LLHPMSQHGM & 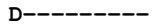 & -ー-ー-ーD & EVLMWKFDS & RLAFHHMARE & LHPEYY \\
\hline$\ldots \ldots \ldots c$ & ..I. & E------- & --- & $2 \ldots$ & $\cdots$ & \\
\hline- -.A...C &. $\mathrm{GN}$ & -- & 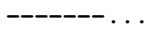 & & & \\
\hline$\ldots$ T. & .I.L... & . TEGEVLMWK & DSLHGM & & & $\mathrm{K}$. \\
\hline $\mathrm{K} \ldots \ldots \mathrm{K}$ & $\ldots$. . &.- & -- & ... & v... & 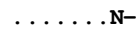 \\
\hline$\ldots$ & $\ldots \ldots \ldots \ldots$ &.-- & 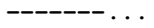 & $\ldots$ & . & \\
\hline . & $\ldots \ldots$ & --- & --- & . & & \\
\hline$\cdots$ & $\ldots \ldots \ldots I$ & E---- & ------ & K...Q. & $\ldots \ldots$ & $\ldots$ \\
\hline.$T$ & $\ldots \ldots$ 工 $\ldots$ & ----- & ------- . & $\cdots$ & $\ldots \ldots$ & . \\
\hline . R & $\ldots$. C... & --- & ------- & . E. & $\ldots \ldots$ & $\ldots$ \\
\hline . C & $\ldots \ldots I$ & -- & ------- & . & . & $\cdots$ \\
\hline & $\cdots$ & - & & $\mathrm{K}$ & $\cdots$ & $\mathrm{K}$. \\
\hline-- . & . AN &.--- & --- & 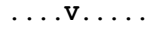 & $\ldots \mathrm{K}$ & \\
\hline.$I$ & .NL . . . & ---- & ------- & $\ldots$ & $\ldots \ldots v \ldots$ & \\
\hline$\ldots \mathrm{C}$ & $\ldots I$ & - & -- & . & . & M. \\
\hline . & $\cdots$ & $\cdot$ & -- & $\mathrm{K}$. & $\cdots$ & n. \\
\hline & .. & - & --- & & .v... & \\
\hline . C & V & - & - & .. & . . к. . & $\ldots F$ \\
\hline I & & -- & - & & $\begin{array}{l}\ldots \ldots \mathrm{v} \\
\ldots \mathrm{R}\end{array}$ & \\
\hline
\end{tabular}

\section{Figure 4}

Consensus Nef protein sequences for gut tissues of HIV-I patients. Consensus Nef protein sequences were obtained for the esophagus (E), stomach (S), duodenum (D), and colorectum (C). No specific signature sequences were observed for any of the gut tissues. 


\section{HIV-I diversity in different gut tissues}

To determine to what extent viral diversity differed among the different gut tissues, the mean total (d), and nonsynonymous $\left(\mathrm{d}_{\mathrm{N}}\right)$ pair-wise distances were calculated for the Nef and RT encoding sequences obtained from the esophagus, stomach, duodenum and colorectum tissues of all patients (Fig. 5). Significantly lower $\mathrm{d}_{\text {and }} \mathrm{d}_{\mathrm{N}}$ values (i.e. codon/amino acid changing substitutions) were observed for the RT encoding region for both the esophagus and the duodenum, compared to the stomach and colorectum ( $\mathrm{p}<0.001$ and $\mathrm{p}<0.05$, respectively). In contrast, for the Nef encoding region, a significantly higher $\mathrm{d}$ value was observed in both duodenum and colorectum ( $\mathrm{p}$ $<0.05)$. Further analysis of the Nef encoding region
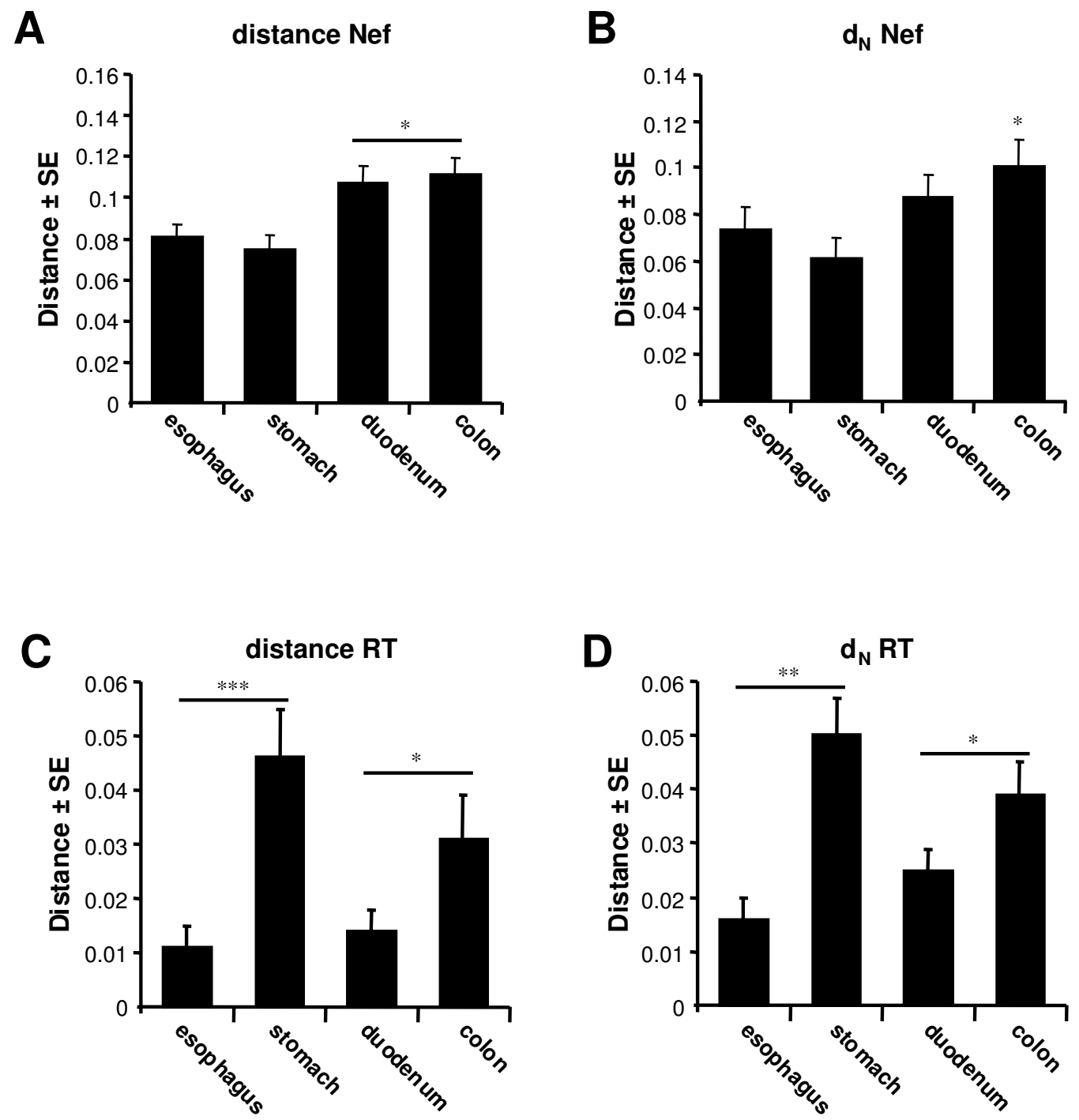

Figure 5

Viral molecular diversity of the Nef encoding region in gut tissues of HIV-I patients. Viral Nef sequences were more diverse (higher mean total distance (d)) for the duodenum and colon compared to the stomach and esophagus (A). Moreover, viral evolution tended towards a more diverse Nef protein in the colorectum as reflected by a significantly higher mean total non-synonomous distance $\left(d_{N}\right.$, i.e. amino acid changing mutations) (B). A similar analysis of the RT coding region of HIV-I, also revealed significant differences in viral molecular diversity in the different tissues for both mean total distance (d) (C) and non-synonomous distance $\left(d_{N}\right)(D)$. These observations indicated that different selection pressures were acting in different parts of the gut depending on the viral region. $(*=p<0.05, * *=p<0.01 * * *,=p<0.00$ I, Dunn's multiple comparison test). 
revealed a higher $d_{N}$ value in the colorectum ( $\left.p<0.05\right)$, suggestive of a more diverse Nef protein in the colorectum. Similar to the analysis of the consensus Nef protein sequences (Fig. 4), analysis of all the inferred protein sequences for both the Nef and RT protein obtained from the different patients did not reveal any signature sequences for any of the tissue compartments, nor were there any obvious differences in domains important for protein function [36-39,48-50](data not shown).

\section{Increased viral replication and nef gene expression in the colorectum of HIV-I infected patients}

The differences in viral diversity suggested that HIV-1 evolved to varying degrees in the different gut tissues. A previous report observed differences in viral loads between blood and colorectum [51], indicative of differences in viral growth between these compartments. To extend the observations obtained with our phylogenetic analysis, we used real-time RT-PCR to determine the relative levels of viral genomic RNA in our patients in esophagus, stomach, duodenum and colorectum (Fig. 6A). The fold increase in transcript levels was expressed relative to the levels observed in the esophagus, since in all patients we found the lowest level of transcript in this tissue. Significantly higher levels of viral genomic RNA in the colorectum compared to esophagus were observed in the 8 patients analyzed in this study ( $\mathrm{p}<0.05)$, suggesting HIV1 replication differs in different parts of the gut. Finally, as our results indicated a more diverse Nef protein in the colorectum, we used real-time RT-PCR to analyze the expression of all HIV-1 RNA transcripts (genomic and mRNAs) containing the Nef protein open reading frame (Fig. 6B), as well as nef gene specific mRNA transcripts [52](Fig. 6C) in the different gut tissues. Indeed, an increased expression of viral mRNA and nef gene specific mRNA transcripts $(\mathrm{p}<0.05)$ was observed among all patients in the colorectum.

\section{Discussion}

The current study clearly indicated that different genes of HIV-1 evolved differently in different parts of the gut. Previous studies have shown that HIV-1 quasispecies found within a patient in the colorectum were different from those found in blood and brain [29,53], suggesting that gut is a separate evolving compartment for HIV-1 replication. To our knowledge our study is the first demonstration that HIV-1 replication in the gut is in itself further compartmentalized. Distinct viral quasispecies were found in the esophagus, stomach, duodenum and colorectum that were different from those found in the periphery (PBL). The data also indicated that viral replication and viral nef gene expression, varied across the gut tissues. The results obtained for the Nef protein encoding region in our cohort is the most convincing evidence of compartmentalization of HIV-1 replication, resulting in the evolu- tion of different HIV-1 quasispecies in different parts of the gut.

Varying viral diversity was observed for both the Nef and the reverse transciptase (RT) encoding region in the gut. Both regions are primarily targeted by the cellular immune response, which will significantly impact viral quasispecies evolution [32-34]. However, their role in determining viral replication and infectivity could also shape viral evolution in these different gut tissue compartments [8,29-31]. The RT region did not exhibit the same pattern of clearly defined clustering that was observed for the Nef encoding region. As the RT region is highly conserved due to its importance in viral replication, distinct clustering would be less likely to be picked up in these phylogenetic analyses due to high levels of sequence homology. However, despite the lack of clustering of the RT region, we did observe a consistent clustering pattern of a large number of stomach and esophagus derived sequences from different patients. This could suggest that there are particular requirements for the RT protein for the infection of the esophageal and stomach tissues, but we did not observe distinct RT protein sequence motifs. Alternatively, the immune system could have selected for specific RT protein sequences in these tissues. This is consistent with compartmentalization of the infection of the gut by HIV-1, and again illustrated that the RT is under different selection pressures compared to the Nef encoding region.

Of particular interest was the more diverse nef gene in the colorectum among the patients. Differences in immune selection pressures in the colorectum could push viral evolution towards more diverse nef sequences. The Nef protein plays a role in determining HIV-1 infectivity and viral replication [30,31]. The observed differences could reflect different adaptation of HIV-1 to the colorectal tissues, which may explain the higher viral RNA and the increased nef gene expression in the colorectum, further supporting compartmentalization of HIV-1 replication in the gut. Alternatively, the differences in viral replication in the different gut tissues could be the result of different levels of infection due to differences in the amount of infectable cells (i.e. CD $4^{+}$cells) in those tissues, or differences in the amount of viral RNA produced by each infected cell. In turn, the elevated viral replication could result in higher viral diversity in the colorectum due to increased error prone replication. Of note, in the brain all these factors not only affect viral evolution and compartmentalization of viral replication, but also play an important role in pathogenesis (reviewed in [54]).

The patients analyzed in the current study were primarily chosen based on their HIV/AIDS status and not selected on any other common pathological features. In addition, 


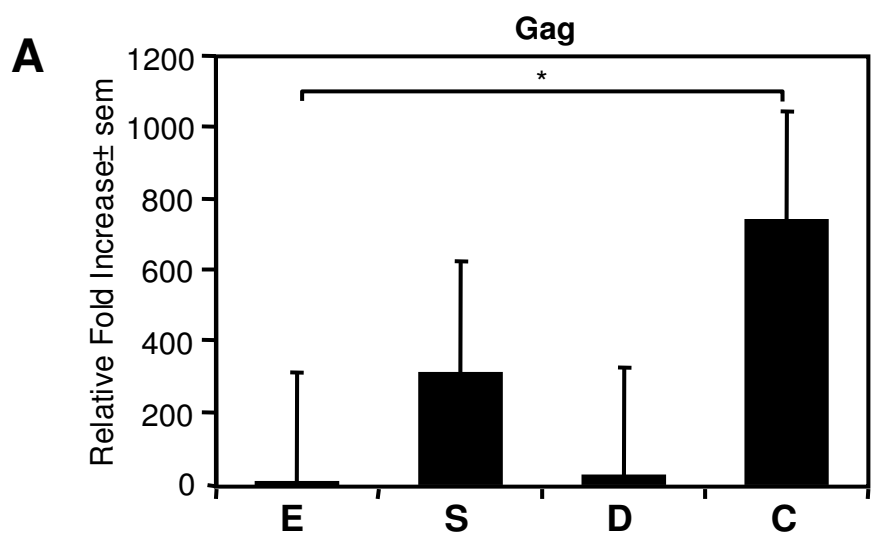

B
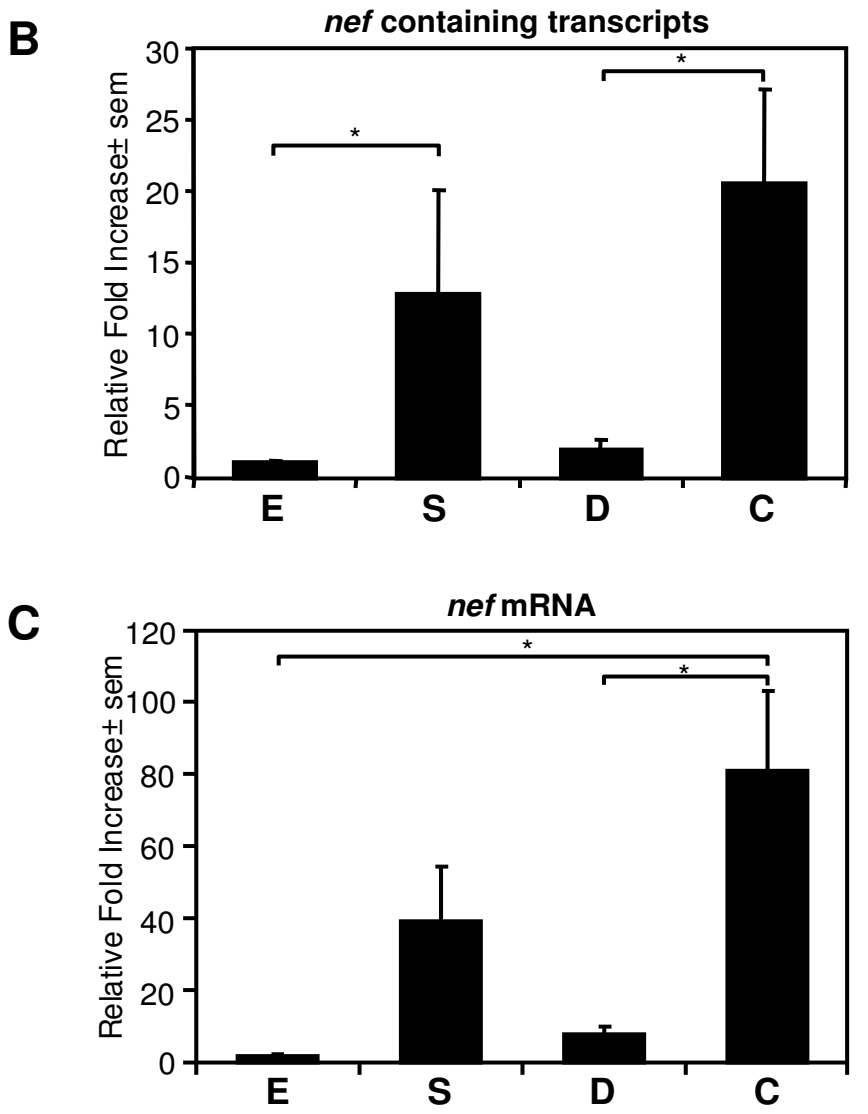

\section{Figure 6}

Real-time RT-PCR analysis of viral expression in gut tissues. (A) Real-time RT-PCR analysis of gag gene expression levels (viral genomic RNA normalized against GAPDH mRNA levels) in the esophagus (E), stomach (S), duodenum (D) and colorectum (C) tissue of HIV-I infected individuals. Increased viral gag gene (viral genomic transcripts) expression in the colorectal tissues compared to the esophagus were observed. All gag expression levels were expressed relative to the gag expression levels in the esophagus ( $*=p<0.05$, Dunn's multiple comparison test). Real-time RT-PCR analysis of all viral RNAs (genomic as well as viral mRNA transcripts) containing the Nef protein open reading frame (B) and nef gene specific mRNA expression levels (C) (normalized against GAPDH mRNA levels) in the esophagus (E), stomach (S), duodenum (D) and colorectum (C) tissue of HIV-I infected individuals. Differing RNA expression levels with increased viral nef gene expression in the colorectal tissues were observed. Again all RNA expression levels were expressed relative to the RNA expression levels in the esophagus $(*=p<0.05$, Dunn's multiple comparison test). 
as our sequences were derived from DNA, we did not sample the viruses that were actively replicating and responsible for pathogenesis in the different tissues. This may explain why we did not find any clear differences in sequence motifs in the Nef protein that could be linked to viral pathogenesis or altered protein function [36-39]. Alternatively, the lack of common features among the Nef protein sequences may be due to the fact that in specific patients the Nef protein may play a major role in pathogenesis, while in others it may not. More patients will need to be analyzed to address this question. Nonetheless, our results clearly indicated that different HIV-1 strains end up in the different tissues. This could be the result of particular tissue requirements for HIV-1, immune selection, as well as the earlier mentioned differences in the number of HIV-1 infectable cells in these tissues. The latter may also be reflected by the clustering of Nef protein encoding sequences by upper and lower GI tissues in some of the patients. The immune response and the cells of the upper or lower GI tissues may have distinct features in common, thereby selecting for more related HIV-1 varieties. However, as we only observed this clearly in two of the patients analyzed, this may not be a common feature. Again, the implications of these observations for HIV-1 pathogenesis remain to be determined.

Despite the fact we did not find direct links to pathogenesis in our analyses, the clustering and differing viral diversity of the Nef protein encoding sequences is of interest. The Nef protein plays many roles in pathogenesis, which is underscored by the observation that deletions in the nef gene, rendering the protein nonfunctional, have been associated with long-term non-progression or absence of HIV-1 associated neurological disease [40-47]. Indeed, the Nef protein has many cytotoxic properties[37-39,5561]. It has both apoptotic and anti-apoptotic activities, and also has various effects on the infected cell (reviewed in $[47,55-57])$. The Nef protein also has proinflammatory actions and its expression results in the induction of cytokines and chemokines, which is affected by the Nef protein sequence [62-64]. Given the important pathogenic role proposed for gut mucosal inflammation in CD4 ${ }^{+}$cell depletion, $[1,2,4,5]$, our observations may also point to a pathogenic role for the Nef protein in the gut. This notion is strengthened by previous observations in HIV/AIDS patients with neurological disease in which increased viral diversity in blood and brain was associated with neurological impairment [14]. The reverse is also true, and we have shown that for the Nef encoding region, viral evolution tended towards a more conserved and possible more pathogenic Nef protein in the brain [62]. These and other observations indicate that host-dependent selection pressures can push viral evolution towards viral strains with a more pathogenic phenotype, which is relevant for both systemic and organ specific pathogenesis
[7,14-16]. The increased viral diversity of the Nef protein encoding region in the colorectum may be the result of increased viral replication. This could increase the chance of pathogenic HIV-1 strains evolving in this part of the gut. Further studies involving patients categorized by pathology will be required to determine to what extent this plays a role in HIV-1 pathogenesis, and are currently ongoing in the laboratory.

Finally, it has been proposed that HIV-1 can "hide" in the gut from antiretroviral therapy [2]. It is also possible that the gut could act as a reservoir for pathogenic viral strains that are not easily identified in the periphery, in that respect acting as a "hide out". Our results showed that different HIV-1 quasispecies were found in the gut tissues that differed from those found in the PBL within each patient, which would be consistent with this notion. However, analysis of multiple viral regions of the actively replicating viruses in the different tissues over multiple visits will be necessary. These studies will allow us to determine how the gut is seeded, and if the different gut tissues not only act as "hide-outs" for HIV-1 drug resistant strains, but also as reservoirs for pathogenic viral strains.

\section{Conclusion}

In conclusion, our observations indicate that the different parts of gut act as distinct compartments for HIV-1 replication containing different HIV-1 quasispecies. These results suggest that the gut could contribute to overall viral diversity. Together with the important role the gut plays as host-pathogen interface in the development of AIDS, this has major implications for treatment of this devastating disease. The complex nature of the gut viral reservoirs has to be taken into account when designing therapeutic approaches, as the gut may be a sanctuary site for drug resistant strains or a source of pathogenic HIV-1 strains.

\section{Materials and methods \\ Patients}

Patients were enrolled from a previously described cohort of HIV seropositive homosexual men followed at the Southern Alberta Clinic (SAC), Calgary, Alberta, from 1993 to 1996 [6,27]. This study was reviewed and approved by the Office of Medical Bioethics of the University of Calgary and all patients signed an informed consent at enrollment. Patients were prospectively followed and laboratory testing included plasma viral load and CD4 counts, for each patient during each visit. In addition upper and lower endoscopies were performed in order to harvest tissue for further testing. This cohort was recruited prior to the introduction of HAART (Highly Active Antiretroviral therapy) at the SAC in late 1997. Antiviral therapies during the study consisted of no treatment, monotreatments with AZT, DDI, DDC, D4T, and 3TC or combinations thereof. 


\section{Gut biopsy samples}

Gastrointestinal tract biopsies were taken during the study period at the level of the esophagus, stomach, duodenum and colorectum. The biopsies taken via endoscopic procedure were shipped cryopreserved and stored at $-70^{\circ} \mathrm{C}$, within 1 hour of collection [6]. Plasma or serum was collected and stored at $-70^{\circ} \mathrm{C}$ and peripheral blood lymphocytes (PBL) were isolated and stored in liquid nitrogen[6,27]. Eight patients at various clinical stages of HIV infection/AIDS were selected. All patients had a CD4 count of lower than 400 at the time of biopsy (Table 1). Nucleic acid sequence analyses were performed on the gut biopsies taken at one visit for this subset of patients.

\section{Nucleic acid isolation and PCR amplification of viral sequence from PBL and gut biopsies}

Chromosomal DNA was isolated from the tissue biopsies from each patient using Trizol Reagent (Invitrogen, Burlington, ON). The HIV-1 proviral DNA regions encoding the Nef (negative factor) and RT (reverse transcriptase) protein were amplified using a nested PCR and $0.2 \mu \mathrm{g}$ of chromosomal DNA as template. The nested PCR protocol for both the first and second round PCR, consisted of an initial denaturation step of $5 \mathrm{~min}$ at $94^{\circ} \mathrm{C}, 45$ cycles of 1 $\min$ at $95^{\circ} \mathrm{C}, 1 \mathrm{~min}$ at the annealing temperature of the primer set used, $2 \mathrm{~min}$ at $72^{\circ} \mathrm{C}$, followed by a final extension step of $10 \mathrm{~min}$ at $72^{\circ} \mathrm{C}$. For the nef region, the primers used for the first round PCR were NEF8678F 5'-GTA GCT GAG GGG ACA GAT AG-3' and NEF9540R 5'-AGG CTC AGA TCT GGT GTA AC-3' $\left(\mathrm{T}_{\mathrm{m}}=50^{\circ} \mathrm{C}\right)$, and for the second round NEF8748F 5'-GAA GAA TAA GAC AGG GCT-3' and NEF9425R 5'-AGT CCC CAG CGG AAA GTC CC-3' $\left(\mathrm{T}_{\mathrm{m}}=40^{\circ} \mathrm{C}\right)[62]$. For the RT region, the first round primers consisted of RT2470 5'-GTA CAG TAT TAG GAC CTA CAC CTG-3' and RT3261 5'-ATC AGG ATG GAG TTC ATA ACC CAT CCA- $3^{\prime}\left(\mathrm{T}_{\mathrm{m}}=55^{\circ} \mathrm{C}\right)$, and for the second round consisted of RT2604 5'-CCA AAA GTT AAA CAA TGG CCA TTG ACA-3' and RT3251 5'-AGT TCA TAA CCC ATC CAA AG-3' $\left(\mathrm{T}_{\mathrm{m}}=55^{\circ} \mathrm{C}\right)$. All viral sequences were amplified using $p f u$ polymerase to reduce introduction of mutations during amplification. In addition, dilution experiments of the template were performed to prevent selective amplification of the most dominant viral sequences at the expense of less frequent viral sequences, and thus skewing sampling of the viral quasispecies. For these experiments, 2 to 10 fold dilutions of the template DNA were made. The dilutions at which still an abundant PCR product could be obtained were used for our sequence analysis.

\section{Sequence and phylogenetic analysis}

The resulting Nef and RT encoding PCR fragments were isolated from gel using the Qiaquick gel extraction kit (Qiagen Inc., Mississauga, ON) and directly sequenced to obtain overall consensus sequences for the different tissue compartments. In addition, the gel purified PCR fragment were cloned by filling in the incomplete fragment ends with Klenow, phosphorylation using T4 polynucleotide kinase, and insertion into the EcoRV site of pSL1180. All enzymes were obtained from Invitrogen (Burlington, ON) and New England Biolabs (Pickering, ON) and used according to the manufacturer's specifications. Where possible up to five to ten clones per patient/sample were analyzed to determine the composition of the viral quasispecies for the Nef and RT encoding region. DNA sequences were determined by automated sequencing on an ABI sequencer (Applied Biosystems, Streetsville, ON) and a Li-Cor 4300 DNA Analysis sequencing system (Licor Biosciences, Lincoln, NE) according to the manufacturers' protocols and reagents. All sequences have been submitted to Genbank (accession numbers EF656787 to $\underline{\text { EF657121) }}$

The inferred amino acid sequence for each cloned nucleic acid fragment was obtained for each sample. These protein sequences were screened for the integrity of the coding sequences (i.e. stop codons, deletions and/or insertions), as well as common amino acid motifs between the different patients and samples. In addition, changes in amino acid residues or motifs that have been shown to be important for function of the Nef and RT protein were analyzed [36-39,48-50]. The nucleic acid sequences were subjected to an extensive phylogenetic analysis, using the MEGA version 3.1 software package [65]. Neighbor-Joining trees were constructed using the Kimura-2-parameter model with 5000 replicates for the bootstrap analysis. Bootstrap values of $>70$ were considered significant. Reference sequences of prototypic HIV isolates were included to rule out possible contamination with laboratory strains. The MEGA software was also used to calculate mean total $(\mathrm{d})$, nonsynonymous $\left(\mathrm{d}_{\mathrm{N}}\right.$, i.e. codon changing substitutions) and synonymous $\left(\mathrm{d}_{\mathrm{S}}\right.$, i.e. non-codon changing substitutions) distances for the nucleic acid sequences from all patient and tissue compartments as well as for individual tissue samples. All distances and phylogenetic analyses were performed through pair-wise comparison and pair-wise gap stripping of each sequence.

\section{Real-time PCR analysis of viral genome and nef gene expression in the gut tissues}

Total RNA was isolated from the gut tissues using Trizol (Life Technologies, Burlington ON) and used as template for the synthesis of cDNA using a previous described protocol $[62,66]$. Real-time quantitative PCR using this cDNA and the iCycler IQ system (Bio-Rad, Mississauga, Canada) was performed as follows. The cDNA was diluted $1 / 1$ with water, and $5 \mu \mathrm{l}$ was used per PCR reaction. Each $25 \mu \mathrm{l}$ reaction contained $5 \mu \mathrm{l}$ of cDNA, $11.5 \mu \mathrm{l}$ of Supermix (BioRad), $6.5 \mu$ l of SYBR-Green (1/50,000 dilution; Bio-Rad), 
$1 \mu \mathrm{l}$ of fluorescein (1/10,000; Bio-Rad), and $1 \mu \mathrm{l}$ of primer mix. The amplification protocol consisted of an initial denaturation step of $3 \mathrm{~min}$ at $95^{\circ} \mathrm{C}$, followed by 45 cycles of $95^{\circ} \mathrm{C}$ for $30 \mathrm{~s}, 30 \mathrm{~s}$ at the annealing temperature $\left(\mathrm{T}_{\mathrm{m}}\right)$ of the primers, and $72^{\circ} \mathrm{C}$ for $30 \mathrm{~s}$, and a final elongation step of $72^{\circ} \mathrm{C}$ for $1 \mathrm{~min}$. The amplicons were subjected to a melt curve analysis to ensure proper amplification, in which the temperature was raised from 65 to $99^{\circ} \mathrm{C}$ in $1^{\circ} \mathrm{C}$ increments, and data acquired for $8 \mathrm{~s}$ at each temperature increment. The viral genome, nef containing RNA, and nef mRNA levels were normalized against GAPDH (glyceraldehyde-3-phosphate dehydrogenase) and expressed as relative fold change compared to the RNA levels in the esophagus. All real-time RT-PCR quantifications were performed in duplicate and repeated with two different batches of cDNA. The primers used were: nef Forward (NEF8748F) 5'-GAA GAA TAA GAC AGG GCT-3', Reverse (NEF8879R) 5'-TCC CAC CCC ATC TGC TGC TGG-3' $\left(\mathrm{Tm}=50^{\circ} \mathrm{C}, 2.5 \mu \mathrm{M}\right.$ each primer) [62], HIV-1 gag Forward 5'-TGC TAT GTC AGT TCC CCT TGG TTC TCT-3', and Reverse 5'-AGT TGG AGG ACA TCA AGC AGC CAT GCA AAT-3' $\left(\mathrm{Tm}=60^{\circ} \mathrm{C}, 2.5 \mu \mathrm{M}\right.$ each primer)[67], nef mRNA Forward 5'-GGC TAA CTA GGG AAC CCA CTG G-3', Reverse 5'-CAG GGA AGT AGC CTT GTG TGT GG-3' (Tm $=50^{\circ} \mathrm{C}, 10 \mu \mathrm{M}$ each primer) [52], GAPDH Forward 5'GAA GGT GAA GGT CGG AGT C-3', Reverse 5'-GAA GAT GGT GAT GGG ATT TC-3' $\left(\mathrm{Tm}=50-60^{\circ} \mathrm{C}, 2.5 \mu \mathrm{M}\right.$ each primer).

\section{Statistical analyses}

All statistical analyses were performed using Graphpad InStat Version 3.01. (GraphPad Software, San Diego, CA) and $p$ values $<0.05$ were considered significant.

\section{Competing interests}

The author(s) declare that they have no competing interests.

\section{Authors' contributions}

GvM, MJG, and DLC collected and analyzed data, designed the study, recruited patients and were involved in writing the paper. DK, LM and TG were involved in designing the methods for collecting, analyzing and interpreting data, and helped putting the data and parts of the manuscript together for publication.

\section{Acknowledgements}

We would like to thank the patients and the staff of the Southern Alberta HIV Clinic for their support, and Tineke Schollaardt and Kris Cannon for technical assistance. LM is a recipient of an Alberta Heritage for Medical Research (AHFMR) studentship. This research was supported by grants from the National Health Research Development Program (NHRDP), the undergraduate student research program (USRP) University of Calgary, Canadian Institutes of Health Research (CIHR), the Canada Foundation for Innovation (CFI), and Alberta Innovation and Science (AIS).

\section{References}

I. Li Q, Duan L, Estes JD, Ma ZM, Rourke T, Wang Y, Reilly C, Carlis J, Miller CJ, Haase AT: Peak SIV replication in resting memory CD4+ $T$ cells depletes gut lamina propria CD4+ $T$ cells. Nature 2005, 434: I |48-II52.

2. Guadalupe M, Sankaran S, George MD, Reay E, Verhoeven D, Shacklett BL, Flamm J, Wegelin J, Prindiville T, Dandekar S: Viral Suppression and Immune Restoration in the Gastrointestinal Mucosa of Human Immunodeficiency Virus Type I-Infected Patients Initiating Therapy during Primary or Chronic Infection. J Virol 2006, 80:8236-8247.

3. Sankaran S, Guadalupe M, Reay E, George MD, Flamm J, Prindiville T, Dandekar S: Gut mucosal T cell responses and gene expression correlate with protection against disease in long-term HIV-I-infected nonprogressors. Proc Natl Acad Sci U S A 2005, 102:9860-9865.

4. Mattapallil JJ, Douek DC, Hill B, Nishimura Y, Martin M, Roederer M: Massive infection and loss of memory CD4+ $T$ cells in multiple tissues during acute SIV infection. Nature 2005, 434: 1093-1097.

5. Guadalupe M, Reay E, Sankaran S, Prindiville T, Flamm J, McNeil A, Dandekar S: Severe CD4+ T-cell depletion in gut lymphoid tissue during primary human immunodeficiency virus type $I$ infection and substantial delay in restoration following highly active antiretroviral therapy. J Virol 2003, 77: I I708-1 I7 I7.

6. al-Mulla W, Church D, Gill MJ: Phenotypic variations and switches in HIV isolated from the blood and the gastrointestinal tissues of patients with HIV-I infection. HIV/GI Research Study Group. J Med Virol 1997, 52:31-34.

7. Shankarappa R, Margolick JB, Gange SJ, Rodrigo AG, Upchurch D, Farzadegan H, Gupta P, Rinaldo CR, Learn GH, He X, Huang XL, Mullins Jl: Consistent viral evolutionary changes associated with the progression of human immunodeficiency virus type I infection. J Virol 1999, 73:10489-10502.

8. Roberts JD, Bebenek K, Kunkel TA: The accuracy of reverse transcriptase from HIV-I. Science 1988, 242:I I7I-I I73.

9. Wodarz $D$, Nowak MA: The effect of different immune responses on the evolution of virulent CXCR4-tropic HIV. Proc Biol Sci 1998, 265(I4I I):2 |49-2I 58.

10. Wolfs TF, de Jong JJ, Van den Berg H, Tijnagel JM, Krone WJ, Goudsmit J: Evolution of sequences encoding the principal neutralization epitope of human immunodeficiency virus $I$ is host dependent, rapid, and continuous. Proc Natl Acad Sci U S A 1990, 87:9938-9942.

II. Craigo JK, Patterson BK, Paranjpe S, Kulka K, Ding M, Mellors J, Montelaro RC, Gupta P: Persistent HIV type I infection in semen and blood compartments in patients after long-term potent antiretroviral therapy. AIDS Res Hum Retroviruses 2004, 20:1196-1209.

12. Altfeld M, Rosenberg ES, Shankarappa R, Mukherjee JS, Hecht FM, Eldridge RL, Addo MM, Poon SH, Phillips MN, Robbins GK, Sax PE, Boswell S, Kahn JO, Brander C, Goulder PJ, Levy JA, Mullins JI, Walker BD: Cellular immune responses and viral diversity in individuals treated during acute and early HIV-I infection. J Exp Med 2001, 193:169-180.

13. Overbaugh J, Bangham CR: Selection forces and constraints on retroviral sequence variation. Science 200I, 292:I I06-II 09.

14. van Marle G, Rourke SB, Zhang K, Silva C, Ethier J, Gill MJ, Power C: HIV dementia patients exhibit reduced viral neutralization and increased envelope sequence diversity in blood and brain. AIDS 2002, 16:1905-1914.

15. Voulgaropoulou F, Tan B, Soares M, Hahn B, Ratner L: Distinct human immunodeficiency virus strains in the bone marrow are associated with the development of thrombocytopenia. J Virol 1999, 73:3497-3504.

16. Song B, Cayabyab M, Phan N, Wang L, Axthelm MK, Letvin NL, Sodroski JG: Neutralization sensitivity of a simian-human immunodeficiency virus (SHIV-HXBC2P 3.2N) isolated from an infected rhesus macaque with neurological disease. Virology 2004, 322:168-18I.

17. Ritola K, Robertson K, Fiscus SA, Hall C, Swanstrom R: Increased human immunodeficiency virus type I (HIV-I) env compartmentalization in the presence of HIV-I-associated dementia. J Virol 2005, 79: I0830-10834.

18. Sheehy N, Desselberger U, Whitwell H, Ball JK: Concurrent evolution of regions of the envelope and polymerase genes of 
human immunodeficiency virus type I during zidovudine (AZT) therapy. J Gen Virol 1996, 77:107I-I08I.

19. Brown AJ, Cleland A: Independent evolution of the env and pol genes of HIV-I during zidovudine therapy. Aids 1996, 10:1067-1073.

20. Frost SD, Gunthard HF, Wong JK, Havlir D, Richman DD, Leigh Brown A): Evidence for positive selection driving the evolution of HIV-I env under potent antiviral therapy. Virology 200I, 284:250-258.

21. Azzali G: Structure, lymphatic vascularization and lymphocyte migration in mucosa-associated lymphoid tissue. Immunol Rev 2003, 195: I78-I89.

22. Hein WR: Organization of mucosal lymphoid tissue. Curr Top Microbiol Immunol 1999, 236: I-15

23. Fujimura $\mathrm{Y}$, Hosobe M, Kihara T: Ultrastructural study of M cells from colonic lymphoid nodules obtained by colonoscopic biopsy. Dig Dis Sci 1992, 37:1089-1098.

24. O'Leary AD, Sweeney EC: Lymphoglandular complexes of the colon: structure and distribution. Histopathology 1986, 10:267-283.

25. Hayday A, Theodoridis E, Ramsburg E, Shires J: Intraepithelial lymphocytes: exploring the Third Way in immunology. Nat Immunol 200I, 2:997-1003.

26. Veazey RS, Mansfield KG, Tham IC, Carville AC, Shvetz DE, Forand AE, Lackner AA: Dynamics of CCR5 expression by CD4(+) T cells in lymphoid tissues during simian immunodeficiency virus infection. J Virol 2000, 74: II00I-I I007.

27. Gill MJ, Sutherland LR, Church D, The Univeristy of Calgary Gastrointestinal/HIV study Group: Gastrointestinal tissue cultures for HIV in HIV-infected/AIDS patients. AIDS 1992, 6:553-556.

28. Ostrowski MA, Chun TW, Justement SJ, Motola I, Spinelli MA, Adelsberger J, Ehler LA, Mizell SB, Hallahan CW, Fauci AS: Both memory and CD45RA+/CD62L+ naive CD4(+) $T$ cells are infected in human immunodeficiency virus type I-infected individuals. J Virol 1999, 73:6430-6435.

29. Wong JK, Ignacio CC, Torriani F, Havlir D, Fitch NJ, Richman DD: In vivo compartmentalization of human immunodeficiency virus: evidence from the examination of pol sequences from autopsy tissues. J Virol 1997, 71:2059-207I.

30. Miller MD, Warmerdam MT, Gaston I, Greene WC, Feinberg MB: The human immunodeficiency virus-I nef gene product: a positive factor for viral infection and replication in primary lymphocytes and macrophages. J Exp Med 1994, 179:101-II3.

31. Papkalla A, Munch J, Otto C, Kirchhoff F: Nef enhances human immunodeficiency virus type I infectivity and replication independently of viral coreceptor tropism. J Virol 2002, 76:8455-8459.

32. Lichterfeld M, Yu XG, Cohen D, Addo MM, Malenfant J, Perkins B, Pae E, Johnston MN, Strick D, Allen TM, Rosenberg ES, Korber B, Walker BD, Altfeld M: HIV-I Nef is preferentially recognized by CD8 $T$ cells in primary HIV-I infection despite a relatively high degree of genetic diversity. Aids 2004, I 8: I 383-1392.

33. Haas G, Samri A, Gomard E, Hosmalin A, Duntze J, Bouley JM, Ihlenfeldt HG, Katlama C, Autran B: Cytotoxic T-cell responses to HIV-I reverse transcriptase, integrase and protease. Aids 1998, I 2: | 427-| 436

34. Yusim K, Kesmir C, Gaschen B, Addo MM, Altfeld M, Brunak S, Chigaev A, Detours $V$, Korber BT: Clustering patterns of cytotoxic T-lymphocyte epitopes in human immunodeficiency virus type I (HIV-I) proteins reveal imprints of immune evasion on HIV-I global variation. J Virol 2002, 76:8757-8768.

35. Gaschen B, Taylor J, Yusim K, Foley B, Gao F, Lang D, Novitsky V, Haynes B, Hahn BH, Bhattacharya T, Korber B: Diversity considerations in HIV-I vaccine selection. Science 2002, 296:2354-2360.

36. Geyer M, Fackler OT, Peterlin BM: Structure--function relationships in HIV-I Nef. EMBO Rep 200I, 2:580-585.

37. Priceputu E, Hanna Z, Hu C, Simard MC, Vincent P, Wildum S, Schinder $M$, Kirchhoff F, Jolicoeur $P$ : Primary human immunodeficiency virus type I nef alleles show major differences in pathogenicity in transgenic mice. J Virol 2007, $81: 4677-4693$.

38. Vincent P, Priceputu E, Kay D, Saksela K, Jolicoeur P, Hanna Z: Activation of p2I-activated kinase 2 and its association with Nef are conserved in murine cells but are not sufficient to induce an AIDS-like disease in CD4C/HIV transgenic mice. J Biol Chem 2006, 281:6940-6954.
39. Hanna Z, Priceputu E, Hu C, Vincent P, Jolicoeur P: HIV-I Nef mutations abrogating downregulation of CD4 affect other Nef functions and show reduced pathogenicity in transgenic mice. Virology 2006, 346:40-52.

40. Kirchhoff F, Greenough TC, Brettler DB, Sullivan JL, Desrosiers RC: Brief report: absence of intact nef sequences in a long-term survivor with nonprogressive HIV-I infection. N Engl J Med 1995, 332:228-232.

4I. Rhodes DI, Ashton L, Solomon A, Carr A, Cooper D, Kaldor J, Deacon N: Characterization of three nef-defective human immunodeficiency virus type I strains associated with long-term nonprogression. Australian Long-Term Nonprogressor Study Group. J Virol 2000, 74: 1058I-10588.

42. Salvi R, Garbuglia AR, Di Caro A, Pulciani S, Montella F, Benedetto A: Grossly defective nef gene sequences in a human immunodeficiency virus type I-seropositive long-term nonprogressor. J Virol 1998, 72:3646-3657.

43. Walker PR, Ketunuti M, Choge IA, Meyers T, Gray G, Holmes EC, Morris L: Polymorphisms in Nef associated with different clinical outcomes in HIV type I subtype C-infected children. AIDS Res Hum Retroviruses 2007, 23:204-2I 5.

44. Cho YK, Lim JY, Jung YS, Oh SK, Lee HJ, Sung H: High frequency of grossly deleted nef genes in HIV-I infected long-term slow progressors treated with Korean red ginseng. Curr HIV Res 2006, 4:447-457.

45. Churchill M, Sterjovski J, Gray L, Cowley D, Chatfield C, Learmont J, Sullivan JS, Crowe SM, Mills J, Brew BJ, Wesselingh SL, McPhee DA, Gorry PR: Longitudinal analysis of nef/long terminal repeatdeleted HIV-I in blood and cerebrospinal fluid of a long-term survivor who developed HIV-associated dementia. J Infect Dis 2004, 190:218I-2186.

46. Deacon NJ, Tsykin A, Solomon A, Smith K, Ludford-Menting M, Hooker DJ, McPhee DA, Greenway AL, Ellett A, Chatfield C, et al.: Genomic structure of an attenuated quasi species of HIV-I from a blood transfusion donor and recipients. Science 1995, 270:988-991.

47. Gorry PR, McPhee DA, Verity E, Dyer WB, Wesselingh SL, Learmont J, Sullivan JS, Roche M, Zaunders JJ, Gabuzda D, Crowe SM, Mills J, Lewin SR, Brew BJ, Cunningham AL, Churchill MJ: Pathogenicity and immunogenicity of attenuated, nef-deleted HIV-I strains in vivo. Retrovirology 2007, 4:66.

48. Roeth JF, Collins KL: Human immunodeficiency virus type I Nef: adapting to intracellular trafficking pathways. Microbiol Mol Biol Rev 2006, 70:548-563.

49. Ren J, Stammers DK: HIV reverse transcriptase structures: designing new inhibitors and understanding mechanisms of drug resistance. Trends Pharmacol Sci 2005, 26:4-7.

50. Sarafianos SG, Das K, Ding J, Boyer PL, Hughes SH, Arnold E: Touching the heart of HIV-I drug resistance: the fingers close down on the dNTP at the polymerase active site. Chem Biol 1999 , 6:RI37-46.

5I. Zuckerman RA, Whittington WL, Celum CL, Collis TK, Lucchetti AJ, Sanchez JL, Hughes JP, Coombs RW: Higher concentration of HIV RNA in rectal mucosa secretions than in blood and seminal plasma, among men who have sex with men, independent of antiretroviral therapy. J Infect Dis 2004, 190: I56-16I.

52. Courcoul M, Patience C, Rey F, Blanc D, Harmache A, Sire J, Vigne R, Spire B: Peripheral blood mononuclear cells produce normal amounts of defective Vif- human immunodeficiency virus type I particles which are restricted for the preretrotranscription steps. J Virol 1995, 69:2068-2074.

53. Wang TH, Donaldson YK, Brettle RP, Bell JE, Simmonds P: Identification of shared populations of human immunodeficiency virus type I infecting microglia and tissue macrophages outside the central nervous system. J Virol 200I, 75: I 1686-II699.

54. Ghafouri M, Amini S, Khalili K, Sawaya BE: HIV-I associated dementia: symptoms and causes. Retrovirology 2006, 3:28.

55. Doms RW, Trono D: The plasma membrane as a combat zone in the HIV battlefield. Genes Dev 2000, I 4:2677-2688.

56. Piguet $\mathrm{V}$, Trono $\mathrm{D}$ : The Nef protein of primate lentiviruses. Rev Med Virol 1999, 9: III-I 20.

57. Fackler OT, Baur AS: Live and let die: Nef functions beyond HIV replication. Immunity 2002, 16:493-497.

58. Simard MC, Chrobak P, Kay DG, Hanna Z, Jothy S, Jolicoeur P: Expression of simian immunodeficiency virus nef in immune 
cells of transgenic mice leads to a severe AIDS-like disease. J Virol 2002, 76:398I-3995.

59. Hanna Z, Weng X, Kay DG, Poudrier J, Lowell C, Jolicoeur P: The pathogenicity of human immunodeficiency virus (HIV) type I Nef in CD4C/HIV transgenic mice is abolished by mutation of its SH3-binding domain, and disease development is delayed in the absence of Hck. J Virol 200I, 75:9378-9392.

60. Hanna Z, Kay DG, Cool M, Jothy S, Rebai N, Jolicoeur P: Transgenic mice expressing human immunodeficiency virus type $I$ in immune cells develop a severe AIDS-like disease. J Virol 1998, 72:12I-132.

6I. Hanna Z, Kay DG, Rebai N, Guimond A, Jothy S, Jolicoeur P: Nef harbors a major determinant of pathogenicity for an AIDSlike disease induced by HIV-I in transgenic mice. Cell 1998, 95:163-175.

62. van Marle G, Henry S, Todoruk T, Sullivan A, Silva C, Rourke SB, Holden J, McArthur J, Gill MJ, Power C: Human Immunodeficiency Virus Type I Nef protein mediates neural cell death: A neurotoxic role for IP-10. Virology 2004, 329:302-318.

63. Federico M, Percario Z, Olivetta E, Fiorucci G, Muratori C, Micheli A, Romeo G, Affabris E: HIV-I Nef activates STATI in human monocytes/macrophages through the release of soluble factors. Blood 200I, 98:2752-276I.

64. Olivetta E, Percario Z, Fiorucci G, Mattia G, Schiavoni I, Dennis C, Jager J, Harris M, Romeo G, Affabris E, Federico M: HIV-I Nef induces the release of inflammatory factors from human monocyte/macrophages: involvement of Nef endocytotic signals and NF-kappa B activation. I Immunol 2003, I70:17|6-1727.

65. Kumar S, Tamura K, Nei M: MEGA3: Integrated software for Molecular Evolutionary Genetics Analysis and sequence alignment. Brief Bioinform 2004, 5:150-163.

66. Boven LA, Vergnolle N, Henry SD, Silva C, Imai Y, Holden J, Warren $\mathrm{K}$, Hollenberg MD, Power C: Up-regulation of proteinase-activated receptor I expression in astrocytes during HIV encephalitis. J Immunol 2003, I 70:2638-2646.

67. Gibellini D, Vitone F, Gori E, La Placa M, Re MC: Quantitative detection of human immunodeficiency virus type I (HIV-I) viral load by SYBR green real-time RT-PCR technique in HIV-I seropositive patients. J Virol Methods 2004, I I 5: I83-I89.

\section{Publish with Bio Med Central and every scientist can read your work free of charge}

"BioMed Central will be the most significant development for disseminating the results of biomedical research in our lifetime. "

Sir Paul Nurse, Cancer Research UK

Your research papers will be:

- available free of charge to the entire biomedical community

- peer reviewed and published immediately upon acceptance

- cited in PubMed and archived on PubMed Central

- yours - you keep the copyright

Submit your manuscript here:

http://www.biomedcentral.com/info/publishing_adv.asp
BioMedcentral 